\title{
A FACTUAL STUDY OF BANKRUPTCY ADMINISTRATION AND SOME SUGGESTIONS
}

Bankruptcy administration has been subject to but little fundamental change in the thirty-three years since the present act was adopted. $^{1}$ Though amendments have frequently been made, ${ }^{2}$ they have altered only the detail, not the general structure. But there is a suspicion that things have changed in respect to bankruptcy or at least that various assumptions basic to the system have been disproved or need to be qualified. Further, it is felt that the system has acquired or inherited from older times a rigidity that prevents it from adequately adjusting itself to the exigencies of the life with which it deals.

Strange as it may seem, data illustrative of how it works or what it does, what kind and manner of people it touches and how it affects them, are not available without independent studies. ${ }^{3}$ We have established an institution and endowed it. We have furnished it with an intricate mechanism. We have given it high legal sanction. We have thrust upon it major social and economic functions. Yet we have saved to ourselves no method of taking its inventory, of evaluating its technique or of appraising its method.

Fortunately an increasing fund of data has recently been made available. ${ }^{4}$ While it is not exhaustive or definitive it is suggestive. On

${ }^{1}$ The present act was adopted in 1898. See 30 Stat. 544 (1898), 24 U. S. C. A. $\$ 58$ (1927).

32 Stat. $797^{\circ}$ (1903), 11 U. S. C. A. $\$ 11$ (1927); 34 Stat. 267 (1906), 11 U. S. C. A. § 104 (1927); 36 Stat. 838 (1910), 11 U. S. C. A. \$ 11 (1927); 39 Stat. 999 (1917), 11 U. S. C. A. $\$ 35$ (1927) ; 42 Stat. 354 (1922), 11 U. S. C. A. $\S 35$ (1927) ; 44 Stat. 662 (1926), 11 U. S. C. A. §§ 1, 11, 21 (1927).

${ }^{3}$ The only data systematically collected are contained in the Annual Reports of the Attorney-General. That they are hopelessly inadequate for any analysis of the operation of the system is evidenced by the fact that in the bankruptcy study being now concluded by the Department of Justice it was found necessary to send out to all the referees and clerks long and detailed questionnaires to obtain data on the operation of the system in the various districts.

Certain it is that in any revision of the bankruptcy system special consideration should be given to this problem and machinery be designed to collect and make available in public records data respecting the operation of the system. Further consideration of this problem will be dealt with in a subsequent article. In this connection the annual reports of the Board of Trade in England showing certain "vital" statistics respecting the English bankruptcy act should be noted. See also Douglas, Some Functional Aspects of Bankruptcy (1932) 41 YALE L. J. 329.

${ }^{4}$ Most recent and exhaustive are the investigations in the Southern District of New York conducted under the direction of Hon. William J. Donovan from 1929-1930 and the study just being concluded by the Department of Justice under the direction of Hon. Thomas D. Thacher, with the assistance of $\mathrm{Mr}$. Lloyd K. Garrison. The Donovan report is reprinted in Administration of Bankrupt Estates (Gov. Print. Off. 1931) House Com mItree PrInt. 71st Cong. 3d Sess. The report of the Department of Justice at the time of this writing has 
its basis an attempt will be made to evaluate certain aspects of bankruptcy. While these comments fall short of a critique of the entire system, they open avenues of attack to a few of the major problems confronting bankruptcy administration today and suggest methods for making that administration more effective.

\section{Creditor Control}

The act is bottomed on the theory of creditor control. Provision is made for election of a trustee by creditors (section 44 ) ; for opposition to an application for a discharge (section 14) ; for confirmation of a composition (section 12) ; for meetings of creditors (section 55 ) ; and for examination of the bankrupt (sections 21 and 55). Further, the interest and concern of creditors in all proceedings is assumed by the mandatory provision in section 58 for ten day notices to creditors of examinations of the bankrupt, of hearings on the confirmation of compositions, of all meetings of creditors, of all proposed sales of property, of declaration and time of payment of dividends, of filing and examination of final accounts of trustees, etc., and for thirty day notice of application for a discharge. The theory doubtless was that the creditors, being the most interested and concerned in the liquidation of the affairs of the debtor, would become active in the management of the estate and vigilant in its administration.

But the experience of the last thirty-three years has disproved conclusively the desirability of such great reliance upon creditors. Their lethargy has become notorious. Instead of fulfilling vigilantly and energetically the role provided for them, they have become paralyzed into inactivity and unconcern. And the reasons therefor are not difficult to divine. The predominance of absentee creditors makes it difficult for the creditors as a group to know intimately the affairs of the debtor or, even if they knew, to give to the administration a personal and dominating influence. But perhaps more important is the fact that dividends on the average have been so small, and in so many cases non-existent, that the time and expense of an active interest and concern would be tantamount to throwing good money after bad. Thus

not been made public. Some statistics collected during the course of that survey, however, have been made available. See Thacher, Proposed Change in Bankruptcy Act (1931) 3 N. Y. State Bar Assoc. Bull. 532.

Furthermore, the Yale Law School in 1930 made a study from the court records of 1004 bankruptcy cases which were closed in the District of New Jersey during the fiscal year ended June 30, 1929. These cases constituted all but 37 of the cases closed during that period. They are referred to herein as the New Jersey cases. Acknowledgment is made to Hon. William Clark of the District Court of the District of New Jersey for his assistance in making possible that study. For a report on other bankruptcy cases studied in New Jersey and Massachusetts, see Douglas, supra note 3. 
the average return to creditors on their claims during the last six years has amounted to not much over $8 \% .^{5}$ In this connection the data obtained from the $1004 \mathrm{New}$ Jersey cases are of interest. In 955 of those cases the petition was sustained. The realized assets were only $30 \%$ of the claims proved and allowed; and after administration costs were paid, dividends of less than $15 \%$ were left for creditors. But this does not mean that all creditors received $15 \%$. The total scheduled liabilities exceeded by almost $100 \%$ the claims actually filed, thus reducing the percentage of realization to creditors, figured on scheduled liabilities rather than on claims filed, to about $7 \%$. The actual average dividends received by creditors who filed their claims were about $15 \%$.

Many realities, however, are lost in averages. The reason creditors are fully justified in assuming that the filing of proofs of claim is often only a futile and expensive gesture is demonstrated clearly in a consideration of the cases in the small asset groups. It is reported ${ }^{6}$ that for the nation as a whole, $82 \%$ of all cases closed during the fiscal year ended June 30, 1930 had either no assets or realized assets of less than $\$ 500$. $65 \%$ had no assets whatsoever, over and above exemptions. When the assets were from $\$ 1$ to $\$ 100$ the percentage of assets consumed in administration expenses was $85 \%$; in asset groups from $\$ 101$ to $\$ 250$, the expense was $73 \%$; and in asset groups from $\$ 251$ to $\$ 500$, the expense was $63 \%$.

The data for the New Jersey cases were somewhat comparable. $37 \%$ had no assets. $61 \%$ had no assets or assets less than $\$ 500$. Where realized assets were from $\$ 1$ to $\$ 100$, the administration expenses uniformly totalled $90 \%$; in asset groups from $\$ 101$ to $\$ 250,83 \%$; in asset groups from $\$ 251$ to $\$ 500,76 \%$. Among retailers, contractors, restaurant proprietors and miscellaneous commercial groups these costs took all of the realized assets in over $90 \%$ of those cases where the assets totalled less than $\$ 100$; the situation as respects laborers, clerks, salesmen, etc., and non-commercial groups was only slightly better after the $\$ 100$ level was passed; while for manufacturers, creditors never received anything until assets amounted to more than $\$ 500$.

These data may or may not be an indictment of bankruptcy administration. They are not set forth as a criticism of the present pro-

${ }^{5}$ This is for the country as a whole. See Donovan, supra note 4, at 5; and the annual reports of the Attorney-General. The figures of the Attorney-General on this point must be taken with qualifications. The scheduled liabilities are by no means reliable because there often is duplication of claims in different schedules by the same debtor or of the same claims by different debtors. See Gamer, On Comparing Friendly Adjustment and Bankruptcy (1930) 16 CoRn. L. QUART. 35,61 et seq. The extent of the duplication has never been measured, so far as is known. No attempt to compute the error due to this factor was made in the New Jersey study.

${ }^{6}$ See Thacher, supra note 4, at 534. 
cedure. They are merely demonstrative of the proposition that in the vast majority of the cases there is no incentive for creditors to concern themselves with the affairs of the debtor. The expedient of wiping off the debt and forgetting it is not only simpler but less expensive. In this connection, data showing the extent of creditor participation in various phases of administration are of interest.

\section{A. Election of Trustee}

Figures collected by the Department of Justice ${ }^{7}$ for selected periods and districts 8 show that in about $75 \%$ of the first meetings of creditors for the election of a trustee no one attended. Even in cases of commercial bankruptcy no one attended in about $50 \%$ of the meetings. In cases where the assets ran from $\$ 1500$ to $\$ 5000$ no one attended in about $20 \%$ of the meetings. In the cases where creditors attended these first meetings their representation was as follows: (1) In commercial bankruptcies the total attendance of creditors and proxy holders was less than $20 \%$ of the total number of creditors and in these meetings holders of proxies dominated; (2) Even in the larger cases a minority (in amount) of creditors controlled the elections about $66 \%$ of the time; and in about $40 \%$ of the meetings in such cases less than one-fourth (in amount) of creditors controlled the elections. These minority interests for the most part were represented by proxies. ${ }^{9}$

Exactly comparable data were not available from the New Jersey cases studied. But the following seem exemplary of the same general situation. Out of 886 cases in which a trustee was appointed, in only 105 did creditors directly participate, either by suggestion or election, in the selection of a trustee. In these 105 cases, 70 trustees were elected by creditors and 35 were appointed at the suggestion of creditors. The court records did not affirmatively show, even approximately, how many of these trustees were elected or suggested by proxies rather than by creditors personally. ${ }^{10}$ But it is interesting to note in what kinds of

${ }^{7} I d$., at $542-543$.

${ }^{8}$ The data were obtained from two-thirds of the referees throughout the country for all first meetings of creditors held during the ten weeks ended December 15, 1930, and from other similar reports for such meetings held during the eight weeks ended May 15, 1931.

- Further, it was observed that in the bulk of the cases not more than one or two holders of proxies were present; and that in a considerable portion of the cases claims were solicited, largely by attorneys, trade associations, collection agencies, etc., and very few by creditors. A forceful indictment against the solicitation of proxies is presented in the Donovan report where it is said "it generally happens that a handful of proxies will be sufficient to control the election of a trustee." Donovan, supra note 4 , at 13 .

${ }^{10}$ In 394 of the New Jersey cases the following data were obtained: 5306 creditors out of $9069(58 \%)$ executed proxies; only 101 creditors attended in person any meeting of creditors, including, but not restricted to, meetings for the examination of the bankrupt and the election of a trustee. See also Gamer, supra note 5 , at 54 et seq. 
cases the creditors became sufficiently interested to elect or suggest trustees. Of the 886 cases where a trustee was chosen there were $778(85 \%)$ with assets below $\$ 5000$. Most of the appointments by or at the suggestion of the creditors took place in those cases, viz., 73 out of 105 . But those 73 constitute only $9 \%$ of the 778 . Thus in $91 \%$ of the cases where the assets were less than $\$ 5000$ the trustee was appointed by the court. As respects the 98 cases with assets of $\$ 5000$ or over, different circumstances prevailed. In 32 of those cases $(32 \%)$ the trustee was elected by the creditors or appointed at their suggestion. This difference between the interest and activity of creditors in cases of assets below $\$ 5000$ on the one hand and in cases over that amount on the other seems substantial. And that difference does not so clearly appear until the $\$ 5000$ group is reached. Of course, the evidence is by no means conclusive and at best is merely indicative of a tendency. The number of cases is too small to justify definitive conclusions.

If these facts are generally representative of conditions throughout the country, ${ }^{11}$ it seems clear that the lethargy and lack of interest on the part of creditors should be recognized in formulating a bankruptcy procedure. It would seem desirable to provide for creditor participation in or control over the election of a trustee only in those cases where from past experience they have been shown to have an interest. How large the estate need be in order to elicit such interest obviously cannot be determined from data presently available. But there is some evidence, as noted above, that until the assets reach $\$ 5000$ very little participation in the election of a trustee is present. Accordingly, it is tentatively suggested that in all cases having no assets or assets below $\$ 5000$ the trustee should be appointed by the court or referee; and only in all other cases should creditors elect. In this detail at least, bankruptcy procedure could be made to conform more closely to the realities of the situation with which it deals.

\section{B. Examinations}

Under the present act no one is under a duty to examine the bankrupt. The examination is left entirely to the discretion of the judge or referee on his own initiative or on the application of any officer or creditor. ${ }^{12}$ In view of the notorious lethargy of creditors and the absence of a mandatory provision it might be expected that considerable laxity would be shown. The following data are of interest in that connection. From the study made by the Department of Justice ${ }^{13}$

${ }^{11}$ For supporting data see Donovan, supra note 4 , at 78 et seq.

${ }^{12}$ See $\$ \S 21$ and 55 .

${ }^{13}$ See Thacher, supra note 4, at 538. 
of selected groups of cases, ${ }^{14}$ it was reported that $75 \%$ (1634) were examined only at the first meeting of creditors, and 891 of these 1634 were examined at the first meeting only by the referee. $10 \%$ of the bankrupts (212) were examined under section $21 \mathrm{~A}$; and $15 \%$ (325) were not examined at all.

Exactly comparable data were not obtained from the New Jersey cases; but the following relevant information appeared. Of the 927 cases in which information appeared in the court records, $158(17 \%)$ were subject to no examination whatsoever. In 206 cases (22\%) an examination was held under section $21 \mathrm{~A}$. And in 769 cases $(83 \%)$ some examination was held, including examination at the first meeting of creditors as well as examinations under section 21A. An increasing percentage of no examinations appeared as the assets grew smaller. Thus, of the 403 cases with no assets or assets of less than $\$ 100$, there were no examinations in 106 cases $(34 \%)$. In the 83 cases with assets of over $\$ 5000$ there were no examinations in only $9(11 \%)$.

That so many bankrupts are going through the courts without any examination or questioning as to whence they came and whither they are going. is a serious indictment against the system and is evidence of the unconcern with which one of the greatest of present social and economic problems is faced.

Under the bankruptcy act of England quite different conditions prevail. The examination takes place automatically when a receiving order is made against a debtor, i.e., before the adjudication. On that event the debtor must submit in a prescribed form a verified statement of his affairs. ${ }^{15}$ The forms used for this statement are long and detailed. For traders there are 47 main questions and for non-traders 33. The questions are designed not only to produce accurate and detailed descriptions of the nature and size of assets and liabilities but also to bring to light as many of the antecedents of failure as possible. In other words, the attempt is made through this statement to reconstruct the affairs of the debtor against the background of the previous few years. Thus the complexion of the particular failure is determined. The court is then under a duty to hold a public examination of the debtor, ${ }^{16}$ which proceeds on the basis of such statement of affairs.

Such inquisitorial proceedings differ greatly from the practice

${ }^{14}$ The cases numbered 3062 and the data were obtained from referees apparently for the ten week period ended December 15, 1930.

${ }_{15}$ See 4 \& 5 Geo. V, c. 59, § 14 (1914); Bankruptcy Rules (1915) No. 189.

${ }^{16}$ See 4 \& 5 Geo.V, c. 59, § 15 (1914); Bankruptcy Rules (1915) Nos. 191-194. For more detailed description of the English procedure, see Donovan, supra note 4, at 175 et seq. For recent summaries of the English, German, Italian, Mexican, Japanese, Swedish, Norwegian, Dutch, Danish, Cuban, Swiss, and Belgian bankruptcy acts, see (January, 1931) 5 Journ. Nat. Assoc. Referees IN BANKRUPTCY 82 et seq. 
under our act. As noted above, examination is not mandatory and the number of bankrupts subjected to no examination most striking. Those acquainted with the examination made at the first meeting of creditors know how perfunctory that examination tends to be. It comes at such an early stage of the proceedings that preparation is impossible and little opportunity is afforded to proceed in the light of known facts regarding the affairs of the debtor. Further, even in section 21A examinations, experience has shown that the tendency is to attempt only a discovery of concealed assets and a detection of fraudulent practices. As noted below, the discharge and criminal sections are primarily and almost entirely designed to catch only cases of fraud. Thus they in turn color and affect the whole course of the proceedings and determine its direction. The fact remains that the examination is shallow; its scope decidedly limited. And when that is coupled with the fact that so many bankrupts receive no examination and that an examination is not compulsory, the result is an ineffective device to uncover those facts necessary to an intelligent control of the whole course of the administration.

The situation clearly calls for a basic revision. Reliance on creditors or officials to take the initiative should be abandoned. A positive duty should be placed on the bankrupt to submit to an examination shortly after the adjudication. The model of the English act seems very desirable. In other words, before the examination the bankrupt should be forced to submit a verified statement of his affairs, showing not only his assets and liabilities but also his previous experience, the reasons for his failure and all other facts relevant to an understanding of the nature of the particular bankruptcy. Not only would that furnish a basis for intelligent examination, but if the Bankruptcy Act were modified as respects the discharge section in the manner hereinafter mentioned, it would serve as an intelligent guide to an attempt at greater individualized treatment of various types of bankruptcies.

Only in some such way can bankruptcy be made less of a sanctuary for all insolvents. Only by some such method can any intelligent undertaking for more effective social control over failures be initiated.

\section{DischaRge}

Systematic and thorough examinations are not only important for efficient liquidation but also essential if the discharge section is to fulfill its prophylactic purposes. Furthermore, if the discharge section is to be revised so as to provide for more flexible administration and for greater adaptation to the various types of cases, rigorous and mandatory examinations become indispensable. 
The Act provides ${ }^{17}$ that the "judge shall hear the application for a discharge and such proofs and pleas as may be made in opposition thereto by the trustees or other parties in interest, at such time as will give the trustee or parties in interest a reasonable opportunity to be fully heard; and investigate the merits of the application and discharge the applicant, unless he has" committed one or more of the acts specified. ${ }^{18}$ In the absence of opposition to the discharge the application must be granted. Furthermore, section 14(b) provides that "the trustee shall not interpose objections to a bankrupt's discharge until he shall be authorized so to do by the creditors at a meeting called for that purpose on the application of any creditor." This clause and the other parts of the section have been construed so strictly by the courts that as a result creditors and only creditors can and may take the initiative in the matter. ${ }^{19}$ Knowing their lack of interest and activity, the number

${ }^{17} \S 14(\mathrm{~b})$.

${ }^{18}$ "(1) committed an offense punishable by imprisonment as herein provided; or (2) destroyed, mutilated, falsified, concealed, or failed to keep books of account, or records, from which his financial condition and business transactions might be ascertained; unless the court deem such failure or acts to have been justified, under all the circumstances of the case; or (3) obtained money or property on credit, or obtained an extension or renewal of credit, by making or publishing, or causing to be made or published, in any manner whatsoever, a materially false statement in writing respecting his financial condition; or (4) at any time subsequent to the first day of the twelve months immediately preceding the filing of the petition, transferred, removed, destroyed, or concealed or permitted to be removed, destroyed, or concealed any of his property, with intent to hinder, delay, or defraud his creditors; or (5) has been granted a discharge in bankruptcy within six years; or (6) in the course of proceedings in bankruptcy, refused to obey any lawful order of or to answer any material question approved by the court; or (7) has failed to explain satisfactorily any losses of assets or deficiency of assets to meet his liabilities. ..." For an incisive treatment of the problem of discharge, see Radin, Discharge in Bankruptcy (1931) 9 N. Y. U. L. Q. REv. 39.

io Thus it has been held that even the court has no power on its own motion to interpose objections to a discharge. American State Bank v. Ulrich, 28 F. (2d) 753 (C. C. A. 8th, 1928); cf. Freshman v. Atkins, 269 U. S. 121, 46 Sup. Ct. 41 (1925). Apparently the most that the court can do is to direct that a creditors' meeting be called to consider whether the trustee should be authorized to file objections. American State Bank v. Ulrich, supra; cf. In re Whitney, 250 Fed. 1005 (D. Mass. 1918). Even the duty of the court to "investigate the merits of the application" of discharge as set forth in the introductory sentence of $\S 14$ has been construed to authorize the court to refuse a discharge only when it "acts upon matters of record" or "admitted facts." Freshman v. Atkins, 294 Fed. 867 (C. C. A. 5th, 1923), aff'd, 269 U. S. 121, 46 Sup. Ct. 41 (1925). Furthermore, since $\S 14$ (b) (6) was amended in $1926^{\circ}$ to provide that such meeting be called "on the application of any creditor," a meeting called solely on the authority of the trustee will not suffice as grounds of denying a discharge. In re Schnoll, 44 F.(2d) 857 (S. D. N. Y. 1930); and clearly the trustee can oppose the discharge only when authorized by a meeting of creditors called for that purpose. In $r e$ Solomon, 37 F.(2d) 18 (C. C. A. 2d, 1930). Likewise the referee may not authorize the trustee to oppose the discharge. In re White, 238 Fed. 874 (N. D. Cal. 1917) ; In re Solomon, supra. Even where creditors have authorized the trustee to oppose a discharge, an opportunity is offered the bankrupt to buy them off since such authority may be revoked and the referee compelled to enter an order revoking such authority. In re Ruhlman, 279 Fed. 250 (C. C. A. 2d, 1922). Cf. General Order XXXII as to speed required of a creditor desirous 
of no examinations held, and the perfunctory nature and narrow ambit of most examinations, it is not surprising to learn that few discharges are actually denied. ${ }^{20}$

It is reported ${ }^{21}$ that of the cases filed from September 1, 1926 to March 1, 1929, 85,252 were granted a discharge and $776(.9 \%)$ denied it; and that of the cases closed during the fiscal year ended June 30 , 1930 , approximately 37,277 (non-corporate) bankrupts were granted a discharge and $319(.8 \%)$ denied it. In the cases of merchants and manufacturers 8305 were granted a discharge and $169(.02 \%)$ were denied it. In only $.004 \%$ of the wage earner cases was the discharge denied. The discharge was granted outright in $98 \%$ of the mercantile bankruptcies and in $991 / 2 \%$ of the non-mercantile bankruptcies. ${ }^{22}$

It is also reported ${ }^{23}$ that in 8804 selected cases, ${ }^{24} 294$ meetings were called to authorize the trustee to oppose the bankrupt's discharge..$^{25}$ 219 of these meetings were not attended by creditors in person or by proxy. In the balance, creditors attended, but chiefly by proxy. Thus the lethargy of creditors continues even where the continuing validity of their claims is at stake. This is made even more apparent by the following data. Of 49,928 cases closed in seventy-two districts in the fiscal year ended June 30,1930 , there were disposed of 27,426 applications for discharge. In only 1042 of these cases did creditors file notices

of opposing discharge in his individual capacity. 11 U. S. C. A. $\S 53$ (1927) p. 44 and cases there cited. To the effect that this order inferentially limits all discharge objections to creditors, see In re Walsh, 256 Fed. 653 (C. C. A. 7th, 1919).

The language "other parties in interest" set out in $\S 14(\mathrm{~b})$ has in general been construed to include, in addition to creditors whose claims have been properly scheduled and proved, certain others who may be adversely affected by the granting of a discharge. These include those who have filed a reclamation petition which has not yet been determined [In re Perelstine, $15 \mathrm{~F}$.(2d) 64 (W. D. $\mathrm{Pa}$. 1926)], one holding a claim not dischargeable [In re Feuer, $4 \mathrm{~F}$.(2d) 892 (C. C. A. 2d, 1925); but cf. In re Chandler, 138 Fed. 637 (C. C. A. 7th, 1905) ], one who has a provable claim but has failed to prove it [In re Ruhlman, 279 Fed. 250 (C. C. A. 2d, 1922) ], one holding a contingent or unliquidated claim not provable in bankruptcy $[E x$ parte Traphagen, Fed. Cas. No. 14,140, at 134 (S. D. N. Y. 1842) ]. No mere "volunteer" is entitled to oppose a discharge as a party in interest. In re White, 238 Fed. 874 (N. D. Cal. 1917) (trustee and referee held to be mere "volunteers"); In re Edie, 296 Fed. 245 (W. D. Pa. 1923) (stranger to record not allowed to file objection on behalf of a creditor); In re Walsh, 256 Fed. 653 (C. C. A. 7th, 1919) (referee acting as special master not party in interest).

${ }_{20}$ See also Donovan, supra note 4 , at 104 et seq.

${ }^{21}$ See Thacher, supra note 4 , at 536 et seq.

22 The foregoing figures apparently exclude from consideration cases where no application for discharge was made. The size of that group is not known. The annual reports of the Attorney-General contain no information whatsoever on discharges.

${ }_{23}$ See Thacher, supra note 4 , at 538 et seq.

${ }^{24}$ Cases closed throughout the country during the ten weeks ending December 15,1930 . See Thacher, supra note 4 , at 538 .

${ }_{25}$ As noted above, the trustee may not oppose the application unless so authorized by the creditors. See cases cited, supra note 19. 
of appearance stating that they intended to oppose the discharge. After filing such notices creditors are required to file specifications of their objections within 10 days. ${ }^{26}$ In only 712 of those cases did creditors file such written specifications. And in 108 other cases creditors filed objections at the time of the hearing on the application. In other words, in only 820 cases did creditors object to the granting of the discharge. But in 208 of those cases $(25 \%)$ they withdrew their objections, leaving only 612 to be tried on the basis of the objections. Of these, only 283 were denied a discharge, i.e., $1 \%$ of the total applications. Consequently, in all but about $2 \%$ of the cases the discharges were granted without inquisition or inquiry and as a mere matter of routine.

The conditions in the New Jersey cases were very similar. Of the 903 cases, ${ }^{27}$ applications for discharge were made in 719 . To these 719 applications objections were made by creditors in only 48 cases $(6.6 \%)$. These objections were made in every case solely on the ground of a distinctly fraudulent act on the part of the bankrupt. Only 7 of the 719 applications were denied $(1 \%)$. These 719 cases were composed of 517 of the commercial group (retailers, manufacturers, wholesalers, etc.) and 201 of the non-commercial group (laborers, clerks, salesmen, professional men, etc.). Of the 511 commercial bankrupts, only $6(1 \%)$ were denied the discharge; of the 202 non-commercial bankrupts, only $1(.4 \%)$. This compares favorably with the data collected by the Department of Justice.

It appeared, however, that the discharge was not requested in 184 of the 903 cases. ${ }^{28}$ Taking those cases into consideration the discharge was granted then only in 712 of 903 cases ( $79 \%)$. Some interesting data were obtained on the nature of the cases where discharge was not requested. In 89 of the 184 cases $(42 \%)$, the bankrupt was a corporation and hence might not need a discharge. Since normally the defunct corporation would have to be rehabilitated completely, it might be just as simple and even more advisable to dissolve it and form a new one. In the 95 cases where an individual person failed to apply for a discharge it was known that some had absconded, some died, some were negligent and some feared creditors. But data sufficient to enable an accurate classification of these cases were not obtained. It would be difficult to say that had application been made in each of these 184 cases, the discharge would have been granted in $99 \%$-as was true of the

\footnotetext{
${ }^{28}$ General Order, XXXII, supra note 19.

${ }^{27}$ Excluding 28 cases of insufficient data, 24 cases of compositions and 49 cases of petitions dismissed.

${ }^{28}$ The number of cases studied by the Department of Justice in which there was no application for a discharge has not been reported at the date of this writing.
} 
719 which did apply. It may be that many or most of these 184 withheld application because of the existence of fraud and the opposition of creditors. Even so, the percentage of discharges remains exceedingly high and the percentage of cases where creditors objected strikingly low.

In the 7 cases where the discharge was denied the grounds were concealing or removing assets or falsification of books. The acts complained of were distinctly fraudulent in nature. No case was found where an objection was made or discharge denied for failure to keep books.

The contrast of the English system is striking. The procedure for dispensing discharges is fundamentally different. An inquiry into the affairs of the debtor to ascertain if he is entitled to a discharge is not left to the whim or initiative of creditors. It is provided ${ }^{29}$ that the application for a discharge shall not be heard "until the public examination of the bankrupt is concluded," and that on the hearing

"the Court shall take into consideration a report of the O. R. as to the bankrupt's conduct and affairs (including a report as to the bankrupt's conduct during the proceedings under his bankruptcy), and may either grant or refuse an absolute order of discharge, or suspend the operation of the order for a specified time, or grant an order of discharge subject to any conditions with respect to any earnings or income which may afterwards become due to the bankrupt, or with respect to his after-acquired property:

"Provided that where the bankrupt has committed any misdemeanour under this Act, or any enactment repealed by this Act, or any other misdemeanour connected with his bankruptcy, or any felony connected with his bankruptcy, or where in any case any of the facts hereinafter mentioned are proved, the Court shall either . . . ; and

"(i) refuse the discharge; or

"(ii) suspend the discharge for such period as the Court thinks proper; or

"(iii) suspend the discharge until a dividend of not less than ten shillings in the pound has been paid to the creditors; or

"(iv) require the bankrupt as a condition of his discharge to consent to judgment being entered against him by the O. R. or trustee for any balance or part of any balance of the debts provable under the bankruptcy which is not satisfied at the date of the discharge, such balance or part of any balance of the debts to be paid out of the future earnings or after-acquired property of the bankrupt in such manner and subject to such conditions as the Court may direct; but execution shall not be issued on the judgment without leave of the Court, which leave may be given on proof that the bankrupt has since his discharge acquired property or income available towards payment of his debts:

"Provided that, if at any time after the expiration of two years from the date of any order made under this section the bankrupt satisfies the

${ }^{29} 4$ \& 5 GEo. V, c. $59, \S 26$ (1914), as amended by 16 \& 17 GEo. V, c. 7 (1926). See Donovan, supra note 4 , at 104-105, 182-183. 
Court that there is no reasonable probability of his being in a position to comply with the terms of such order, the Court may modify the terms of the order, or of any substituted order, in such manner and upon such conditions as it may think fit." ${ }^{30}$

Two distinctive features of this act are to be noted: (1) A systematic hearing on the application, based upon the facts elicited from the previous examinations of the bankrupt and his conduct during bankruptcy. Reliance is not placed on creditors to furnish the initiative. As a result no discharge is granted without a hearing. (2) A greater administrative flexibility in dispensing discharges. The court is not restricted to the rather limited alternatives existing under our act of either granting or denying the discharge. All degrees of in-between cases are recognized by providing for suspension or conditional grant of discharges. Thus there is greater adaptation of the penalty to the requirements of the various types of cases. In that connection the following data compiled from the annual reports of the Board of Trade for the

${ }^{30}$ The facts referred to are:

“(a) That the bankrupt's assets are not of a value equal to ten shillings in the pound on the amount of his unsecured liabilities, unless he satisfies the Court that the fact that the assets are not of a value equal to ten shillings in the pound on the amount of his unsecured liabilities has arisen from circumstances for which he cannot justly be held responsible:

"(b) That the bankrupt has omitted to keep such books of account as are usual and proper in the business carried on by him and as sufficiently disclose his business transactions and financial position within the three years immediately preceding his bankruptcy:

"(c) That the bankrupt has continued to trade after knowing himself to be insolvent :

"(d) That the bankrupt has contracted any debt provable in the bankruptcy without having at the time of contracting it any reasonable or probable ground of expectation (proof whereof shall lie on him) of being able to pay it:

"(e) That the bankrupt has failed to account satisfactorily for any loss of assets or for any deficiency of assets to meet his liabilities:

"(f) That the bankrupt has brought on, or contributed to, his bankruptcy by rash and hazardous speculations, or by unjustifiable extravagance in living, or by gambling, or by culpable neglect of his business affairs:

"(g) That the bankrupt has put any of his creditors to unnecessary expense by a frivolous or vexatious defence to any action properly brought against him:

"(h) [That the bankrupt has brought on or contributed to his bankruptcy by incurring unjustifiable expense in bringing any frivolous or vexatious action]:

“(i) That the bankrupt has, within three months preceding the date of the receiving order, when unable to pay his debts as they become due, given an undue preference to any of his creditors:

“"(j) That the bankrupt has, within three months preceding the date of the receiving order, incurred liabilities with a view of making his assets equal to ten shillings in the pound on the amount of his unsecured liabilities:

"(k) That the bankrupt has, on any previous occasion, been adjudged bankrupt, or made a composition or arrangement with his creditors :

"(1) "That the bankrupt has been guilty of any fraud or fraudulent breach of trust." 
years 1924-1929 inclusive are of interest. During that period 5520 discharges were disposed of finally. The dispositions were:

$\begin{array}{cccc}\text { Granted } & \text { Refused } & \text { Conditional } & \text { Suspended } \\ 140(2.7 \%) & 157(2.8 \%) & 1268(22.9 \%) & 3955(71.6 \%)\end{array}$

Specifications of the conditions imposed in the 1268 cases are not available. But as to the 3013 cases for the years 1926-1929 inclusive, where the discharge was suspended, the following were the periods of suspension and the number of cases in each period:

1 day or less................................ 120

Over 1 day but less than 1 month................ 183

Over 1 month but less than 1 year................. 1313

Over 1 year but less than 2 years.................. 470

Over 2 years but less than 3 years................. 620

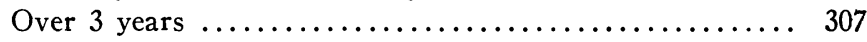

It would be difficult and unfair to attempt a comparison of the disposition of applications for discharge in this country with that in England. As seen from the discharge sections set forth above, the grounds for denying the discharge under our act differ greatly from those specified in the English act for suspending it or granting it conditionally or unconditionally. However, a striking difference in the method of approach to the problem is apparent. Instead of a rather rigid procedure there is an extremely flexible one, susceptible to greater individualized treatment of cases. It is a recognition of the folly of attempting to force all cases into one of two molds, of classifying all bankrupts in the manner of the exclusive duality of our section 14 .

Elsewhere there has been presented the need for greater discrimination between the many types of bankrupts and for a determination of the functions of bankruptcy in light of the realities of the cases that constitute the grist of the mill. ${ }^{31}$ That phase of the problem will not be repeated here. Suffice it to say at this point that whether or not the grounds for objecting to the discharge are increased or modified, the following revisions should be made:

1. A compulsory and systematic hearing on every application for a discharge; and

2. A discretion on the part of the court or other official in charge to refuse, suspend, or grant, unconditionally or conditionally, the discharge in light of the facts and complexions of the individual cases. ${ }^{32}$

${ }^{31}$ See Douglas, supra note 3.

${ }^{32}$ No tightening of the discharge section should ignore the situation as respects the corporation. It is not known how many bankrupts each year are corporations. Of the 1004 New Jersey cases studied, $95(9.5 \%)$ were corporations. And as noted above, 89 of these 95 corporations did not even apply for 


\section{Criminal Provisions}

Very little is known respecting the operation of the criminal provisions of the Bankruptcy Act. ${ }^{33}$ The Annual Reports of the Attorney-

a discharge. Insulation from liability can be so easily and inexpensively obtained under modern statutes that there might follow from a tightening up of discharge a tendency to incorporate before entering business. If this were done the tightening up process would not necessarily be effective as no application for discharge need be made. The problem of effective control over the phenomena of failures-business or otherwise- has so many ramifications that it becomes as extensive and varied as the life which bankruptcy touches or affects. For other aspects of this problem, see Douglas, supra note 3 .

${ }^{33} \$ 29$ provides: "Offenses.-A person shall be punished, by imprisonment for a period not to exceed five years, upon conviction of the offense of having knowingly and fraudulently appropriated to his own use, embezzled, spent, or unlawfully transferred any property or secreted or destroyed any document belonging to a bankrupt estate which came into his charge as trustee, receiver, custodian, or other officer of the court.

"A person shall be punished, by imprisonment for a period not to exceed five years, upon conviction of the offense of having knowingly and fraudulently (1) concealed from the receiver, trustee, United States marshal, or other officer of the court charged with the control or custody of property, or from creditors in composition cases, any of the property belonging to the estate of a bankrupt; or (2) made a false oath or account in, or in relation to any proceeding in bankruptcy; (3) presented under oath any false claim for proof against the estate of a bankrupt, or used any such claim in composition, personally or by agent, proxy, or attorney, or as agent, proxy, or attorney; or (4) received any material amount of property from a bankrupt after the filing of the petition, with intent to defeat this Act; or (5) received or attempted to obtain any money or property, remuneration, compensation, reward, advantage, or promise thereof from any person for acting or forbearing to act in bankruptcy proceedings; or (6) having been an officer or agent of any person or corporation, and in contemplation of the bankruptcy of such person or corporation, or with intent to defeat the operation of this Act, concealed or transferred any of the property of the debtor; or (7) after the filing of the petition, or, in contemplation of bankruptcy, concealed, destroyed, mutilated, or falsified any book, document, or record affecting or relating to the property or affairs of a bankrupt; or (8) after the filing of the petition, withheld from the receiver or trustee any book, document, or paper affecting or relating to the property or affairs of a bankrupt, to the possession of which he is entitled.

"A person shall be punished by fine, not to exceed five hundred dollars, and forfeit his office, and the same shall thereupon become vacant, upon conviction of the offense of having knowingly (1) acted as a referee in a case in which he is directly or indirectly interested; or (2) purchased, while a referee, directly or indirectly, any property of the estate in bankruptcy of which he is referee; or (3) refused, while a referee or trustee, to permit a reasonable opportunity for the inspection of the accounts relating to the affairs of, and the papers and records of, estates in his charge by parties in interest when directed by the court so to do.

"A person shall not be prosecuted for any offense arising under this Act unless the indictment is found or the information is filed in court within three years after the commission of the offense.

"(1) Whenever any referee, receiver, or trustee shall have grounds for believing that any offense under this Act has been committed, or from facts or circumstances brought out in the course of administration or otherwise brought to his attention, that there is reasonable ground to believe that such an offense has been committed, or for special reason, an investigation should be had in connection therewith, it shall be the duty of such referee, receiver, or trustee to report such matter to the United States attorney for the district in which it is believed such an offense has been committed, including in such report a statement of all the facts and circumstances of the case within his knowledge, with 
General merely show with customary succinctness and generality the total convictions, acquittals, nolles, etc., without any specification of the offenses prosecuted, sentences imposed, etc.

But through the courtesy of the Committee for the Study of the Business of the Federal Courts, ${ }^{34}$ appointed by the National Commission on Law Observance and Enforcement, data for the first time have been made available respecting the operation of the criminal provisions of the Bankruptcy Act. The study conducted by that Committee was made in thirteen federal districts ${ }^{35}$ in twelve states. All of the criminal cases, including the bankruptcy cases concluded during the three fiscal years ended June 30,1930 , were taken. The data were obtained solely from the court records. ${ }^{36}$

the names of the witnesses, and a statement as to the offense or offenses believed to have been committed.

"(2) It shall be the duty of every United States attorney immediately to inquire into the fact so reported to him by any referee, receiver, or trustee, and the law applicable thereto, and if it appears probable that any offense under this Act has been committed, in a proper case and without delay, to present the matter to the grand jury, unless upon inquiry and examination such district attorney decides that the ends of public justice do not require that the alleged offense should be investigated or prosecuted, in which case he shall report the facts to the Attorney-General for his direction in the premises." See also §41.

For a statement of the abuses disclosed in New York, see Donovan, supra note 4 , at 40 et seq., 104 et seq.

${ }^{34}$ Composed of Dean Charles E. Clark, Chairman, Professor T. W. Arnold, Dean Henry M. Bates, Pres. Robert M. Hutchins, Dean Orrin K. McMurray, Professor Harold R. Medina, Professor Edmund M. Morgan, Hon. Owen J. Roberts, and Professor William O. Douglas, Sec. The conclusions respecting these data are not set forth as representing the views of the committee but only those of the writers of this article. The report of the Committee covering these bankruptcy cases has not yet been made.

${ }^{35}$ Northern District of California, District of Colorado, District of Connecticut, Northern District of Illinois, District of Kansas, Eastern District of Louisiana, District of Massachusetts, Eastern District of Michigan, Southern District of New York, Western District of North Carolina, Northern District of Ohio, Southern District of Ohio and the Southern District of West Virginia.

The studies in those respective districts were conducted under the supervision of Dean Orrin K. McMurray of the School of Jurisprudence, University of California, former Dean James G. Rogers and Dean Robert L. Stearns of the University of Colorado Law School, Dean Charles E. Clark and Prof. Wm. O. Douglas of the Yale Law School, Dean Henry A. Bigelow and Prof. E. W. Puttkammer of the University of Chicago Law School, Prof. T. E. Atkinson of the University of Kansas Law School, Dean Rufus C. Harris of Tulane University Law School, Prof. E. M. Morgan of Harvard Law School, Dean Henry M. Bates of University of Michigan Law School, Prof. Harold R. Medina of Columbia Law School, Dean Charles T. McCormick of University of North Carolina Law School, Dean Herschel W. Arant and Prof. Silas A. Harris of Ohio State University Law School, and Dean T. W. Arnold and Prof. J. B. Fordham of the University of West Virginia Law School.

${ }^{36}$ For further description of the method and scope of the study, see Progress Report on the Study of the Business of the Federal Courts (Report No. 7 of the National Commission on Law Observance \& Enforcement, 1931). It should be noted that the unit taken for the study was the individual rather than the indictment or information. Thus if two persons were covered by one indictment, it would be treated as two cases. 
Table I shows the nature of the offense prosecuted and the result of the prosecution.

TABLE I

OFFENSES AND Dispositions

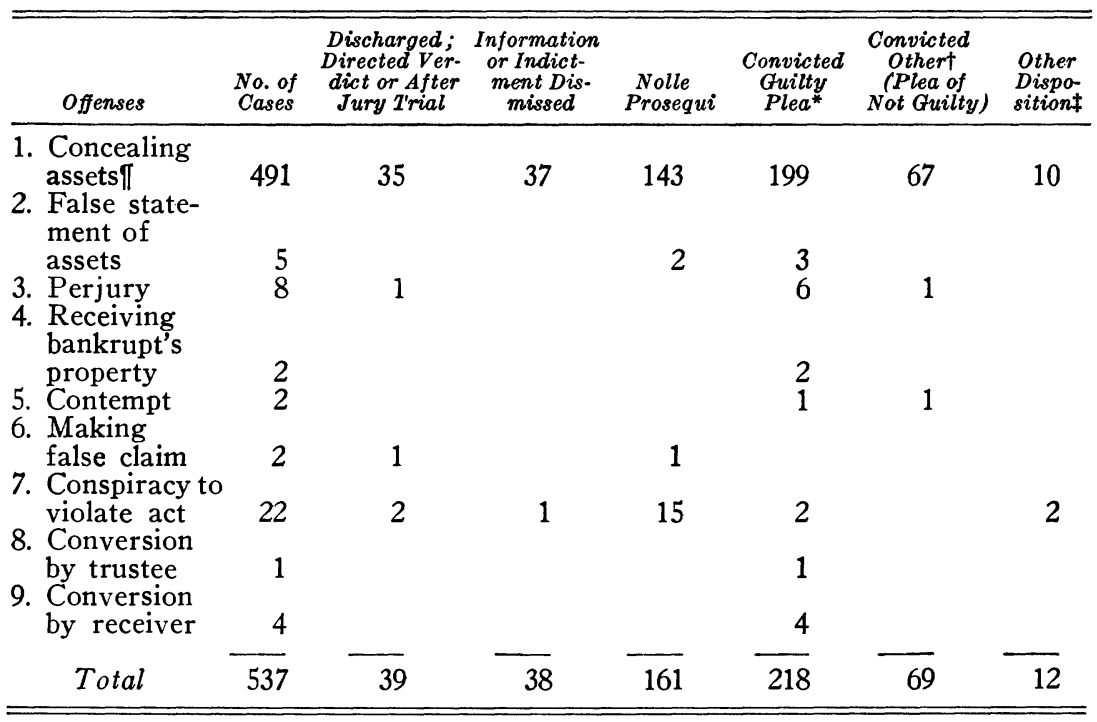

* Includes plea of guilty to part.

$\dagger$ Includes conviction on only some counts.

$\ddagger$ Includes mistrials and removals.

† Includes conspiracy to conceal and concealing of assets combined with perjury, mutilating books, falsifying records, fraudulent conveyances, conspiracy, perjury.

It will be seen that of the total of 537 cases, $491(91 \%)$ involved concealment of assets, conspiracy to conceal, or concealment combined with other offenses such as perjury, mutilation, falsification or withholding of books and records, or fraudulent transfers. A further analysis of the total reveals that 446 of the 491 involved concealment or conspiracy alone and not in combination with other types of offenses. Practically all of the other 45 cases in the group of 491 combined with concealment the offenses of falsification, mutilation, etc., of books and records. The vast majority of the cases then are being brought under section 29 (1), the number of all other cases being relatively insignificant in terms of the total.

The number discharged, dismissed and nolled were 238 or $44 \%$ of the total number of prosecutions. This is a surprisingly high mortality. The nolles alone constituted $29 \%$ of the total. Whatever the conditions which are responsible for this showing, whether inefficient 
prosecution or difficulty of proof of the particular types of offenses to which bankruptcy under the present type of administration is susceptible, they call for a searching reexamination of the whole procedure.

It is interesting to note that in $40 \%$ of the cases ( 218 out of $53 \%$ ), there were convictions on guilty pleas. The use of guilty pleas has been noted elsewhere. ${ }^{37}$ That in 218 of the 287 convictions ( $75 \%$ ) the plea of guilty appeared is not necessarily a condemnation of the procedure. But it is indicative of the major role of the prosecutor in these bankruptcy cases and of the extent of the discretion being employed in that office. Thus it furnishes one focal point for any further effort towards fortifying the present laws and securing more rigorous enforcement. In this connection it should be noted that a jury trial was had in only 11 of the $28 \%$ convictions $(3.8 \%)$, again pointing to the office of the prosecutor as the key point in the further study and analysis of the problem of law enforcement in bankruptcy.

Parenthetically it might be added that of the 69 cases of conviction on pleas of not guilty there were appeals in $16(23 \%)$ of the cases. In four of these there was error.

Table II shows the nature of the sentences imposed.

\begin{tabular}{|c|c|c|c|}
\hline \multicolumn{4}{|c|}{$\begin{array}{l}\text { TABLE II } \\
\text { SENTENCES }\end{array}$} \\
\hline & Guilty Pleas & Not Guilty Pleas & Total \\
\hline \multirow{9}{*}{$\begin{array}{l}\text { Suspended sentence } \\
\text { Probation } \\
\text { Suspended sentence and probation } \\
\text { Sentence-Term: } \\
0-2 \text { months } \\
3-6 \text { months } \\
7-12 \text { months } \\
13-24 \text { months } \\
\text { Over } 24 \text { months }\end{array}$} & 30 & 6 & 36 \\
\hline & 8 & 3 & 11 \\
\hline & 56 & 8 & 64 \\
\hline & & & 27 \\
\hline & $\begin{array}{l}20 \\
35\end{array}$ & $\frac{1}{7}$ & 42 \\
\hline & 33 & 10 & 43 \\
\hline & 20 & 20 & 40 \\
\hline & 0 & 8 & 8 \\
\hline & 36 & 12 & 48 \\
\hline Total & $244^{*}$ & $75 \dagger$ & 319 \\
\hline
\end{tabular}

* Includes 26 duplications, most of which were combinations of fine and suspended sentence.

$\dagger$ Includes six duplications composed of either fine and imprisonment or imprisonment with suspended sentence and probation.

It will be noted how the percentage of the lighter sentences of probation and suspended sentence increases in the case of guilty pleas and how the percentage of imprisonment and fines increases in the case of pleas of not guilty. Likewise, where there is imprisonment, the increase in the percentage of terms over 12 months is more marked in

${ }^{37}$ See $e . g$., Progress Report on the Study of the Business of the Federal Courts, supra note 36 , at 22 et seq. 
cases of pleas of not guilty. Doubtless these reflect the element of bargaining present when guilty pleas are accepted.

The relative insignificance of the fine, the presence of such large numbers of suspended sentences and probations, and such large numbers of imprisonments for short periods indicate the lack of severity in the enforcement of the criminal penalties of the statute. The chances of severity of treatment become quite remote in face of this array of data, for if one survives the discharge, dismissal and nolle stage, he may yet bargain for relatively light sentences and secure them.

The picture thus given of bankruptcy prosecution does not purport to be complete and definitive and obviously cannot be taken as condemnatory of the whole system. But it does present elements of laxity and inefficiency consistent with other aspects of bankruptcy administration considered above. To consider the criminal provisions separate and apart from the whole problem of the administration of bankrupt estates would be foolish. All parts are intimately related. So long as the administration is not vigilant, so long as creditors are relied upon to take responsibilities which they shirk, so long as debtors may proceed blithely through bankruptcy without being interrogated or bothered by officials, so long as the public concern over or interest in the types of persons receiving discharges remains at its present low ebb, the general picture of the criminal aspects of bankruptcy may be expected to remain much the same. Only after making the basic and fundamental changes enumerated above can any material and permanent improvement be made which will be reflected in more vigilant detection and prosecution of offenses. To start with an attempt to improve the criminal provisions and machinery would be to start at the wrong end of the problem.

\section{Assignments, Extensions, and Compositions}

Under section 3 (5) of the Bankruptcy Act, "any general assignment for the benefit of creditors" constitutes an "act of bankruptcy." In other words, if a debtor desires to work out an "extension" with his creditors or to proceed to liquidate his assets with their cooperation or under their direction and does not secure practically $100 \%$ consent of creditors, dissatisfied creditors or creditors made more disgruntled by fee chasing lawyers may petition the case into bankruptcy. ${ }^{38}$ Or unless

${ }^{38}$ Under \& 4(b) of the bankruptcy act a person owing debts of $\$ 1000$ or over may be adjudged an involuntary bankrupt. Of course, where the alleged act of bankruptcy is the assignment, those creditors assenting in the assignment cannot later petition the debtor into involuntary bankruptcy. "In re Houstman, 7 F. (2d) 329 (C. C. A. 9th, 1925). But just what constitutes "consent" is doubtful. Thus it has been held that consent to the assignment with respect to a particular debt does not bar a petition for bankruptcy at the instigation of the same creditor if grounded upon a different claim. Hays v. Wagner, 150 Fed. 533 (C. C. A. 6th, 1907). And consent to an assignment which proves invalid is not consent to a subsequent assignment in which the technical shortcomings of the first assignment were cured. Doty v. Mason, 244 Fed. 587 (S. D. Fla. 1917) 
$100 \%$ consent has been obtained, one dissatisfied creditor may by threats create a high nuisance value or perhaps even proceed to enforce his claims without reference to the cooperative arrangements of the debtor and other creditors.

National statistics showing the extent of these cooperative forms of liquidation and operation of financially embarrassed businesses are not available. But of recent years they have been the subject of an increasing number of studies, and their virtues and disadvantages reviewed and discussed. ${ }^{39}$

A résumé of all of those devices, their nature and operation, will not be attempted at this point. But there is chosen as perhaps generally illustrative of the character of the problem dealt with and the method employed, the so-called "friendly adjustment" sponsored by the National Association of Credit Men. ${ }^{40}$ In the analysis which follows an attempt will be made to ascertain whether the competitive relation between bankruptcy and these voluntary forms of procedure can be removed or reduced and their respective operations effectively integrated and coordinated.

The system of friendly adjustment takes the form of an assignment by the debtor of all his property to a trustee for the benefit of creditors. This trustee is generally the local branch manager of the credit association and the assignment takes place at the instigation of either the creditors or the debtor. The purpose of such assignment may be either to work out an "extension" whereby the business will be continued, or to effect a liquidation of the assets of the debtor. After the local credit manager has had an opportunity to talk with the debtor and ascertain his condition, he generally attempts to bring together all the creditors for the purpose of considering an assignment. This first meet-

${ }^{39}$ For a review of the use of creditors' committees in effecting reorganizations during the inventory deflation of 1920-1921 and a discussion of their advantages and disadvantages (both legal and business), see Dewing, Financial Policy of CoRporations (1926) 1133-1162. For a collection of cases and other materials bearing upon legal aspects of reorganization through creditors' committees, see Douglas and Shanks, Cases and Materials on Corporate ReORGANIZATION (1931) 502-519.

Recent discussions of the type of settlement or adjustment popularly called "friendly adjustment" are to be found in Billig, What Price Bankruptcy: A Plea for "Friendly Adjustment" (1929) 14 CoRn. L. QUART. 4] $\rightarrow$ Billig, Extra-Judicial Administration of Insolvent Estates: $A$ Study of Recent Cases (1930) 78 U. of PA. L. Rev. 293; Gamer, supra note 5. Cf. Michael, Problems of a Common Law Assignee (Dec. 1925) CREDIT CRAFT 32; Incompetent Common Law Trustees (Oct. 1927) N. Y. CRedit MeN's Assoc. Bull.

${ }^{40}$ For the list of "approved" adjustment bureaus organized and operated by the National Association of Credit Men during the last twenty-five years and presently (i.e., in 1930) existing, see Billig, Extra-Judicial Administration of Insolvent Estates, etc., supra note 39, at 295. These "friendly adjustments" are not represented as being necessarily typical of the run of assignments but are set forth as representing perhaps the most highly developed and efficient type of which there is a record. 
ing of creditors generally decides first whether the failure of the debtor to meet his obligations is so tainted with "fraud" or "dishonesty" as to make "friendly adjustment" inadvisable. If, however, such an adjustment is agreed upon, this meeting of creditors decides whether an "extension" or "liquidation" is advisable. ${ }^{41}$ It is essential, as noted above, that practically all of the creditors consent to the assignment lest the entire scheme be disrupted by non-consenting creditors who may seize upon the assignment as an "act of bankruptcy."

Following the assignment, the business is either continued-generally with the debtor in charge but supervised by the trustee-or is wound up by the credit bureau which either assumes complete direction or proceeds under the direction of a creditors' committee. If the creditors give the bureau free rein to attend to the whole matter of extension or liquidation, they take as little part in the process as they do in bankruptcy; they are merely notified as to what occurs or is proposed. Customarily the credit bureau charges a flat $10 \%$ of monies collected as its fee, but this does not necessarily constitute the entire administrative expense. ${ }^{42}$

One of the advantages urged for this method of adjustment is that it results in stimulating active creditor participation, which as already indicated, is lacking in the case of bankruptcy administration. ${ }^{43}$ This conclusion is tentatively borne out by a random sample of friendly adjustment cases which were in the process of settlement in Newark, New Jersey, during the time the New Jersey bankruptcy cases were being studied. ${ }^{44}$. In slightly less than half of these cases, creditors' committees were appointed and apparently took an active part in supervising the sale of assets and devising ways and means of liquidating stock or fixtures. These creditors' committees also supervised the operation of the business during an extension period. Even where a creditors' committee was not appointed, at least half the creditors attended from one to four general creditors' meetings.

Simplified procedure is the dominant characteristic of the liquidation process under the friendly adjustment plan. This is claimed as another of the great advantages of such assignments. Disposals of assets are made in bulk at private sale, notices to creditors are for the

${ }^{41}$ See Billig, What Price Bankruptcy, etc., supra note 39 , at 428 et seq.

${ }^{42}$ Id., at 432 et seq.; Billig, Extra-Judicial Administration of Insolvent Estates, etc., supra note 39 , at 303 et seq. et seq.

${ }^{4}$ See Billig, What Price Bankruptcy, etc., supra note 39, at 422 et seq., 438

${ }^{44}$ There were 30 such cases which were obtained from the current files of the Newark, N. J., adjustment bureau during the spring of 1930 . Acknowledgment is made to Dr. W. C. Plummer of the Department of Commerce for his assistance in this connection, and to the officials in charge for their many courtesies and assistance. 
most part dispensed with and the trustee given a generally free hand to liquidate as quickly as possible. It is insisted that the credit association applies a professional technique to the business of liquidation. With its staff of full-time employees and wide trade contacts, it is said to be able to do a far more efficient job than can a bankruptcy court which has to set up a new liquidating agency (receiver and trustee who are too often not skilled in the particular type of business at hand) to handle each insolvent estate. ${ }^{45}$

It has been argued, however, that the advantages of friendly adjustment over bankruptcy are to a considerable degree illusory-that assumed efficiency reflected in apparently higher percentages of dividends paid arises largely because the cases are highly selected, while bankruptcy must take all comers; that oversimplified procedure results in injustices and preferences that would have no standing at law; that laymen and credit bureaus are hardly competent to pass on matters of "fraud" or "dishonesty"; that the success of friendly adjustment is due not to the system but to excellence of personnel, which excellence is similarly possible under the bankruptcy system. ${ }^{46}$

The various arguments pro and con, however, are beyond the point of this article. It seems clear that many extensions and liquidation assignments are being successfully carried on and that they have many advantages over the administration of debtors' estates by bankruptcy courts. So long as such assignments operate successfully, so long as friendly adjustment reveals a fairly active creditor participation and apparently an efficient administration, it is difficult to see why it should not be utilized and given legal sanction in the Bankruptcy Act. Were section 3 of the Bankruptcy Act so modified as to provide that an assignment for the benefit of creditors should not constitute an act of bankruptcy where the terms of such assignment are approved by a certain majority of creditors in number and amount and filed with a referee in bankruptcy, much would be done to remove the nuisance value of one or two creditors who refuse to join in the assignment and either force immediate payment in full or sit by and wait until the majority have taken the risks of granting an extension, and when the business is going again, press for payment in full. ${ }^{46 a}$ The injustice of a system which

${ }^{45}$ See Billig, Extra-Judicial Administration of Insolvent Estates, etc., supra note 39 , at 297 et seq.

${ }^{48}$ See Gamer, supra note 5 , at 37 et seq.

46a Although an assignment for the benefit of creditors brings the assigned property into custodia legis so as to avoid attachment or garnishment in the hands of the assignee [Reddy v. Raymond, 194 Mass. 367, 80 N. E. 484 (1907)], nevertheless non-assenting creditors may levy upon property in the hands of the trustee if the assignment is "in fraud of or to hinder and delay creditors." $C f$. Reid v. McIntyre, 98 U. S. 507 (1878). Furthermore, in states holding the mere acceptance of the assignment by the assignee to be insufficient consideration to 
permits such practices is illustrated by the Newark friendly adjustment cases discussed above, in which in about one-third of the cases, one or more minority creditors contrived to get themselves paid in full as a result of their power to break up the whole adjustment program if they were not bought off.

Of course any modification of section 3 along the lines suggested should empower the referee to refuse to file the assignment if the plan submitted shows evidence of majority oppression or the court is not satisfied as to the integrity or efficiency of the assignee. A further advantage in according legal sanction to assignments to effectuate extensions or liquidation lies in providing a control over these non-judicial settlements effective to check fraudulent or repeated failures. In the Newark adjustment cases, the credit bureau and the first meeting of creditors generally considered the question of whether the failure was "fraudulent" or "dishonest." But naturally both the credit bureau and the creditors were more interested in the possibility of a substantial return than in impartial inquiry into the nature of the failure. One is impressed with the fact that the inquiry of creditors was not for the purpose of deciding the nature of the debtor's past conduct; it was directed only along the line of deciding whether the debtor would now "cooperate" in a proposed assignment. Accordingly, it seems advisable to include in the foregoing suggested modification of the Bankruptcy Act, a power in the referee to refuse to file an assignment if the causes of the debtor's failure embrace any of those set out in section 14, dealing with grounds for refusing a discharge. This, in effect, is nothing more

support the assignment, non-participating creditors may levy upon the assigned property. Faulkner v. Hyman, 142 Mass. 53, 6 N. E. 846 (1886). And if for any reason the assignment is "void" or "voidable" as where the requirements of the statute on assignment have not been strictly complied with, non-assenting creditors may garnish property in the hands of the assignee. McCord-Norton Shoe Co. v. Brown, 131 Kan. 19, 289 Pac. 417 (1930) (a single non-assenting creditor allowed to garnish property assigned to branch of National Credit Association where assignment technically defective); Doughty v. Weston, 174 App. Div. 212, 160 N. Y. Supp. 1075 (1st Dept. 1916) (assignment to creditors' committee conditioned on unanimous acceptance ineffective to prevent garnishment by non-consenting creditors). But $c f$. Mayfield Woolen Mills v. Goodrich \& Martineau Co., 189 Wis. 406, 207 N. W. 954 (1926) (statute provided against contingency occurring in McCord-Norton case, supra). In any case, a creditor may prosecute his claim to judgment against the assignor [Central Trust Co. of Mobile v. Edward D'Arcy, 238 Mo. 676, 142 S. W. 294 (1911)] which will allow him to recover in full from the assignor if creditors participating in an assignment have released the assignor by sharing pro rata. Such judgment will also permit subsequent attachment of any surplus in the hands of the assignee after participating creditors have been paid [State National Bank v. Wheeler and Mather Mercantile Co., 104 Ark. 222, 148 S. W. 1033 (1912)] as well as the levy of process upon any property not assigned or assignable by the instrument. $C f$. Rainwater-Bradford Hat Co. v. McBride, 117 Fed. 597 (C. C. A. 8th, 1902). Cases such as these illustrate the strength of the dissenter's legal position and the means that may be employed to secure more than a pro rata share of all the debtor's assets. 
than according the court the power to deny a discharge in these nonjudicial settlements. Indeed it might be advisable to go even further and provide that, as is now the law with respect to discharge, no second assignment for the benefit of creditors may be filed within a certain period. ${ }^{47}$

Improved efficiency of friendly adjustment proceedings would be further stimulated if section 1 of the Bankruptcy Act were modified so as to include within its definition of "trustee" an assignee-trustee and thus give to such assignee-trustee the same powers now possessed by a trustee in bankruptcy. Among the main results which should flow from such a modification are the allowance to such an assignee-trustee of the right to examine witnesses before the referee, the investing of the assignee with the same title to the property of the debtor and the same power to avoid preferences and frauduent transfers as are now granted a trustee in bankruptcy, and a similar power of objecting to the claims of certain creditors by causing them to be determined judicially. Of course, such broad powers should be accompanied by the imposition of duties on an assignee-trustee similar to those to which a trustee in bankruptcy is subject. Thus the court or referee should be empowered to supervise the fee charged and to declare void unlawful preferences made by such an assignee-trustee in favor of a particular friendly group of creditors.

The recent case of Garrison v. Pilliod Cabinet Co. ${ }^{47 a}$ illustrates the need of judicial recognition of friendly adjustment settlements. In this case, a branch of the National Association of Credit Men, to which an assignment for the benefit of creditors had been made, was subsequently presumed disqualified to act as a trustee in bankruptcy because of the inconsistency of its position in representing all creditors impartially. Such a holding would be unnecessary if judicial approval and surveillance of the assignee were had from the start.

The debtor, too, should be protected by a provision permitting him to secure a discharge if he has complied and cooperated with the friendly

${ }^{47}$ The problem raised by this suggested provision is illustrated by a series of recent cases dealing with discharge and compositions. Under $\S 14(\mathrm{c})$ of the Bankruptcy Act a confirmed composition gives the debtor his discharge. In re Abrams \& Rubins, 173 Fed. 430 (S. D. N. Y. 1909). And a discharge by composition has been held to preclude a discharge in bankruptcy within six years of the discharge by composition under $\S 14$ (b) (5). In re Massell, 285 Fed. 577 (D. Mass. 1922). It has been but recently decided that the confirmation of a first composition within six years of the application for confirmation of a second composition is not a valid ground for denying the latter. Isberg v. Butler, U. S. Daily, Nov. 23, 1931, at 2160. Thus, unless some discretion is given the referee or court to deny the filing of a second assignment within a specified time of a previous assignment, there is nothing to prevent a whole series of repeated adjustments.

47a 50 F.(2d) 1035 (C. C. A. 10th, 1931). 
adjustment plan. Under the present state of the law, the debtor can only secure his discharge in a friendly adjustment procedure if he is in a sufficiently strong bargaining position to insist upon releases from his creditors. In the Newark friendly adjustment cases, releases were almost never considered.

Of course in the matter of assignments for the benefit of creditors, state statutes may both grant powers and impose duties similar to those which are here suggested for incorporation in the Bankruptcy Act. ${ }^{48}$ But the provisions of state assignment acts vary so greatly and their applicability in a particular case rendered so doubtful by decisions holding that they are, at least in part, supplanted by the Federal Bankruptcy Act, ${ }^{49}$ that a uniform law for the country at large seems desirable.

It would also seem that sections 12 and 13 , governing composition, should be broadened so as to permit courts or referees to confirm extension agreements approved by at least a majority of creditors in number

${ }^{48}$ For example, the New Jersey statute regulating assignments $[1 \mathrm{~N}$. J. Comp. Stat. (1910) 113] provides that assignments must be for the equal benefit of all creditors and that they must be recorded and filed to be valid. The assignee is required to follow a definite mode of making public the assignment so as to give creditors a chance to file their claims; the debtor and assignee must file an inventory of assets under oath and give a bond for the faithful performance of the trust. Lists of creditors must be filed with the surrogate. The assignee is empowered to oppose and contest any creditor's claim in the orphans' court. Final and intermediate accountings by the assignee under oath are required. The assignee, with certain exceptions, takes full legal title to the debtor's estate, and may seek the advice of the court and avoid preferences made or suffered to be made within two months of the assignment. He likewise is granted all powers, which creditors would have, to avoid transfers, conveyances, mortgages, etc. The compensation of the assignee-trustee is regulated as are fees in the proceedings. The assignor is not protected against creditors not exhibiting their claims, but is discharged as to those creditors who do (as to the validity of this provision see note 49, infra). Only those creditors exhibiting their claims within three months of the assignment may share in the dividends.

For other examples of state assignment statutes, see synopses of state laws in Burrill, Assignments (6th ed. 1894) 609-694; and Hawes, Voluntary AsSignments for the Benefit of Creditors (1876) (N. Y. Laws). And $c f$. J. W. Smith, The EQUitable Remedies of CReditors (1899). In the absence of statute an assignee for the benefit of creditors is subject to no judicial supervision beyond that which may be imposed upon trustees generally. The common law assignee for the benefit of creditors "could administer such property as passed to him by deed, but nothing else" and "if the debtor had previously transferred property in fraud of the very creditors for whose benefit the assignment of the remaining property was made, the assignee had no standing to sue for the recovery." GLEN N, CREDitors Rights AND REMEDIES (1915) § 292.

${ }^{49}$ See Boese v. King, 108 U. S. 379, 2 Sup. Ct. 765 (1883), in which the Supreme Court held that the discharge provision of the New Jersey Assignment Statute, cited note 48, supra, was superseded by the Federal Bankruptcy Act of 1867 and thus unconstitutional, but refused to pass upon the question of whether the Bankruptcy Act superseded the state statute for all purposes. $C f$. amendment to New Jersey act passed in 1928 providing that if "for any reason any section or any part of any section... shall be questioned in any court ... the same shall not affect any other . . . provision of this act." N. J. Comp. Stat. (Supp. 1925-1930) 54, §12-31. On the question of how far the Bankruptcy Act has supplanted state laws dealing with insolvent debtors, consult also International Shoe Co. v. Pinkus, 278 U. S. 261, 49 Sup. Ct. 108 (1928). 
and amount and thus again obviate the necessity of securing practically unanimous consent of all the creditors..$^{50}$ Such a change would permit the business-like reorganization of many enterprises through the medium of creditors' committees. Apparently the nuisance value and legal position of a few dissenting claims are some of the main stumbling blocks to efficient management by creditors' committees at the present time. ${ }^{51}$

Revision of the Bankruptcy Act along the lines suggested would result in capitalizing on the devices successfully employed by business men to solve their difficulties by extending to those devices a legal sanction hitherto lacking. As a result it would obviate many of the present competitive features of bankruptcy. Further, it would remove from the system its predominant insistence on treating and administering all cases alike, without consideration of their basic differences. The total result should be the evolution of a system characterized by a business technique designed in the light of the actualities of business problems.

\section{Amortization}

The problem of wage earner bankruptcies is susceptible of similar treatment. If a wage earner desires to pay his obligations why should not provision be made to that end? Due to wage assignments or garnishments or high pressure methods of collection, the wage earner who has indulged - or even overindulged-in consumer credit frequently is so harassed by his creditors that bankruptcy is the only way out. The collection agency camps on his doorstep. He is threatened with dire consequences if he fails to pay. At the time of the purchase of goods on installment or of the loan from a finance company he has signed a contract which assigns his wages to the particular creditor. Or he may have made similar assignments to several creditors. On default of one payment the creditor threatens to file the assignment or to garnish his wages. If that happens, the debtor fears he will lose his job, as his employer does not want to act as bookkeeper for a finance company. The guarantors or co-makers of his note to a finance company may also have assigned their wages as security. They are threatened by the creditor. Accordingly they put pressure on the debtor, as they also fear that their jobs are in danger. Again, the debtor on purchasing or borrowing may have signed as part of the elaborate contract an affidavit that at the time of incurring the particular indebtedness he owes no one else a cent. These are convenient weapons in the hands of creditors. They may be used to turn the screws a little tighter by a threat of prosecution.

How far such collection methods prevail throughout the country

${ }^{50}$ As to the need of providing that a discharge by a confirmed composition bars a subsequent discharge by composition within a specified period, see note 47, supra.

${ }^{51}$ Consult Dewing, op. cit. supra note 39, at 1151. 
it is impossible to say. It is known, however, that they are present in many urban centers. ${ }^{52}$ These conditions are accentuated by the prevalency of state statutes permitting wage assignments. Sometimes these are restricted; at other times they are not effectively controlled. Thus, in Illinois, the wage assignment as security for a loan is valid to the amount of $50 \%$ of the wages and as security for the purchase of goods to $100 \%$ of the wages. ${ }^{53}$ Furthermore, under the law of Illinois and Massachusetts, a wage assignment made before bankruptcy is not affected by a discharge, the court analogizing the security to a mortgage or other lien not disturbed by bankruptcy proceedings. ${ }^{54}$

${ }^{52}$ The situation appears particularly acute in urban centers in Kentucky. For the Kentucky statute on wage assignments, see Ky. Stat. (Carroll, 1930), §4758a. The authors are indebted to $\mathrm{Mr}$. Rolf Nugent of the Department of Remedial Loans of the Russell Sage Foundation for the following information concerning 270 wage earner bankruptcies (selected at random) in the five principal cities of Kentucky (Ashland, Covington, Lexington, Louisville, Paducah) for the year 1929:

Seventy-four and two tenths per cent listed loan companies as creditors. The average number of loan accounts for each borrowing bankrupt was 4.53 . The average size of loan listed was $\$ 39.10$. The average indebtedness to loan companies was $\$ 177$. The approximate monthly cost per borrower was $\$ 25$.

In Louisville, wage earner bankruptcies were approximately $94 \%$ of all bankruptcies for the year 1929. The study of these cases indicates how close is the relationship between bankruptcy and conditions in the small loan field and how bankruptcy may be acting as a corrective to pathological conditions arising out of lack of control over those financing the consumer. On consumer credit see Clark, Financing the Consumer (1930); Bergengren, Credit Union (1931).

${ }_{53}$ The Illinois Loan Shark Law, Ill. Rev. Stat. (Smith-Hurd, 1931) c. 74, $\S 16$, provides that "no assignment of any salary or any wages, earned or to be earned, given to secure any loan shall be valid, unless in writing" and that "under such assignment or order for the payment of future salary or wages given as security for a loan under this act, a sum of fifty (50) per centum of the borrower's salary or wages shall be collectible [collectable] by the licensee from the time that a copy thereof, verified by the oath of the licensee, of his agient, together with a verified statement of the amount unpaid upon such loan, has been served upon the employer." It has been held that this section may not be evaded by two assignments of $50 \%$ each. Snite v. Chicago \& E. I. R. R., 247 Ill. App. 118 (1927).

2 MASs. GeN. LAws (1921) c. 154, governing wage assignments, provides that assignment embraces any instrument purporting to transfer or collect an interest in future wages. No such assignment to secure a loan of less than $\$ 300$ shall be valid as against an employee unless (a) written acceptance is given and assignment recorded, acceptance for recordation to be allowed only if the assignment exempts $\$ 10$ per week of salary; (b) unless a prescribed form is substantially followed; (c) unless the written consent of the wife is given in the case of married men; (d) and in no case shall the assignment be valid for more than one year from making thereof. Wage assignment to secure other than loans of less than $\$ 300$ may not be enforced beyond two years. Such assignment must state interest rates, money value of goods actually furnished and that three fourths of wages are exempt. The wife's consent must be secured in writing.

For a review of the legal and economic phases of wage assignments see the forthcoming report by the Russell Sage Foundation, Department of Remedial Loans, 130 E. 22nd St., New York City. The provisions of the statutes governing wage assignments vary in different states.

${ }^{34}$ Mallin v. Wenham, 209 Ill. 252, 70 N. E. 564 (1904) holds that an assignment of wages to be earned from a specific employment was valid despite the indefinite time for which employment was to run and that such an assignment 
Garnishment or supplementary proceedings, though less effective as pressure devices, are sometimes employed to the same end. ${ }^{55}$ Thus in 221 bankruptcies of salaried individuals studied in Boston in the nine months ended June, $1931,{ }^{56}$ supplementary proceedings were the direct

might be discharged only by payment of the debt or discontinuance of the employment. Held further that such assignment was still a valid claim against the assignor after his discharge in bankruptcy. Accord: Monarch Discount Co. v. C. \& O. Ry., 285 Ill. 233, 120 N. E. 743 (1918) ; Citizens' Loan Ass'n v. Boston \& Maine R. R., 196 Mass. 528, 82 N. E. 696 (1907) (leading Mass. case). Contra: Leitch v. Northern Pacific Ry., 95 Minn. 35, 103 N. W. 704 (1905); In re West, 128 Fed. 205 (D. Ore. 1904). Cf. Draeger v. Wisconsin Steel Co., 194 Ill. App. 440 (1915) (assignment of wages prior to time wage earner secures employment is void and discharge in bankruptcy is good defense to an action for such wages). To the effect that an assignment of all future wages to be earned under an existing employment (italics the court's) may be assigned as security for a merchandise claim and that an agreement between employer and employee that such assignment shall not be made, will not avail the employer when sued by the assignor, see State Street Furniture Co. v. Armour \& Co., 177 N. E. 702 (I1l. 1931), noted in (1931) 86 N. Y. L. J. 1120. Cf. Massie v. Cessna, 239 Ill. 352, 88 N. E. 152 (1909).

The enforceability of a wage assignment after a discharge in bankruptcy of the assignor appears to be governed by the state law defining the nature of the interest assigned. If such assignment creates a valid lien under the state law, that lien is one preserved under $\$ 67 \mathrm{~d}$ of the Bankruptcy Act. Citizens' Loan Ass'n v. Boston \& Maine R. R., supra; 7 Remington, BankRuptcy (3d ed. 1924) \$3454. But $c f$. In re Fellows, 43 F.(2d) 122 (N. D. Okla. 1930) (intimating discharge bars subsequent suit irrespective of state law). Where no lien arises on future wages by state law, it is clear that a discharge in bankruptcy is a good defense to a suit to collect wages due. In re Voorhees, $41 \mathrm{~F}$. (2d) 81 (N. D. Ohio 1930).

${ }^{55}$ Garnishment statutes vary in different states. Ill. Rev. Stat. (Smith-Hurd, 1931) c. $62, \S 14$ : "The wages or salary for services of an employee who is the head of a family and residing with the same to the amount of twenty dollars per week, shall be exempt from garnishment. All above said exempt amount shall be liable to garnishment." If the employede does not fall within the provisions of this section, his wages may be garnished after the manner set forth in c. $62, \S 5$.

Under the Poor Debtor Law of Massachusetts [MAss. Cum. Stat. (1927) c. 224], which went into effect March 1, 1928, a judgment creditor may file application for supplementary process. In that event a summons may issue requiring the debtor to appear and be examined relative to his property and ability to pay. The failure of a debtor to appear without reasonable excuse or to submit to an examination shall constitute contempt of court. The court may issue warrants for arrest to secure the attendance. The court may order the debtor to produce non-exempt property or if the debtor be able to pay the judgment in full or by partial payments the court may, after allowing the debtor out of his income a reasonable amount for support of himself and family, order him to make full or partial payments from time to time. Further the court may at any time renew, revise, modify, suspend or revoke any such order. With minor exceptions there is no appeal. See $\S \S 14,15,16,18$ and 19. This is the law which was the direct cause for the filing of the petition in the wage earner cases discussed infra.

${ }^{58}$ This study was made by the Yale Law School and Institute of Human Relations of Yale University with the cooperation of the Department of Commerce. It was made possible only because of genuine and whole-hearted cooperation on the part of the three distinguished Boston referees, Hon. Arthur Black, Hon. B. Loring Young, and Hon. Charles C. Cabot. The Department of Commerce was represented by Mr. Victor Sadd. The Boston cases studied included 910 cases of all types and classes of bankrupts. Only cases arising in the metropolitan area of Boston (i.e., the counties of Suffolk, Norfolk, and Mid- 
cause of the filing of the petition in practically every case.

The cumulative effect of these various devices employed by creditors frequently is to put the wage earner under a constant, overwhelming and imponderable burden of fear. He may have been improvident. $\mathrm{He}$ may have overindulged in easy credit, made easier by subtle methods of advertisement. He may have been optimistic. Or again illness, partial unemployment, reduction of salary and medical costs may have intervened and made the payment of the promised installments absolutely impossible if he and his family are to be provided with the necessities of life. Yet in spite of his improvidence, ignorance, or misfortune he may be honest and sincerely desirous of avoiding the stigma of bankruptcy. All that he may need is the opportunity to declare a moratorium and amortize his obligations in the light of his ability to pay. Under the present system one rapacious creditor may by insistent and unreasonable demands jeopardize the interests of all other creditors by impoverishing the debtor until bankruptcy is the only feasible solution; or the activities of one creditor may spur on other creditors, each demanding his pound of flesh, each insisting on the letter of the contract. If the debtor goes into bankruptcy the chances are that his creditors will get nothing since his ability to pay is measured only in terms of future earnings.

In this connection, the 221 bankruptcies of salaried persons studied in Boston are significant. As previously noted, in practically every case the direct cause of the filing of the petition was supplementary proceedings. In $75 \%$ of the cases there were no assets. The average amount of assets was $\$ 219$; the average amount of liabilities $\$ 3524$. In 82 cases (13\%) debts were owed to loan and finance companies (not including commercial banks), the average of such debts being $\$ 626$. Likewise, in 82 cases an average of $\$ 420$ each was owed for goods bought on installment. There were 54 different loan and finance companies with claims and 20 credit unions. Eighteen of these loan and finance companies were unlicensed and operating outside the law by charging in excess of the legal $42 \%$ a year interest. Twenty-five of the 221 bankrupts owed these 18 unlicensed companies.

Among the 221 cases there were not more than half a dozen whose bankruptcies bordered on fraud. In not over $7 \%$ of the cases could it be said that there was gross and unjustifiable extravagance on the part of the bankrupt measured as of the time of the incurrence of the in-

dlesex) were covered. About $70 \%$ of all those cases in which petitions were filed between October 1, 1930, and June 30, 1931, were taken. For a report on the methods of investigation, see Douglas and Thomas, The Business Failures Project-II. An. Analysis of Methods of Investigation (1931) 40 YaLE L. J. 1034. For a partial report on the results of the study see Douglas, supra note 3 . 
debtedness. In the balance of the cases the debtors were apparently honest persons engulfed by an overwhelming volume of debts (incurred in more prosperous or normal times) when on the downward turn of the business cycle they lost their jobs or suffered reductions of income; or when illness intervened or the cost of medical care became abnormal. Many other factors were mirrored in these bankruptcies, such as domestic difficulties and accommodation indorsements. But the fact remains that in the vast majority they were cases of varying degrees of misfortune precipitated by the increasing demands on and availability of consumptive credit.

It is understandable that bankruptcy was the only way out for most of these persons. The incessant pressure of creditors, the toll of the poor debtors' court and the fear of losing their jobs were controlling factors. During the year preceding bankruptcy, $5 \%$ had received no salary or income whatsoever; $5 \%$ had received less than $\$ 500 ; 16 \%$ between $\$ 500$ and $\$ 999 ; 23 \%$ between $\$ 1000$ and $\$ 1499 ; 24 \%$ between $\$ 1500$ and $\$ 1999 ; 19 \%$ between $\$ 2000$ and $\$ 2499$; and $8 \%$ over $\$ 2500$. The average salary was $\$ 1526$. Only $54 \%$ had been employed full time; $33 \%$ for half time or more (but less than full time); $8 \%$ worked, but for less than half time; $5 \%$ were completely unemployed. Yet these facts do not mean that with adequate provision for their protection many of these bankrupts would not have undertaken to amortize all or part of their indebtedness. It is believed that their inherent honesty and their desire to avoid if possible the stigma of bankruptcy would have induced many of them to pursue that course rather than bankruptcy.

Amortization of such debts is not wholly theoretical and untried.. It has been successfully demonstrated on a small scale by the National Funding Company in Seattle, Washington, since 1925, and on a larger scale by the American Amortization Company in Chicago, Illinois, since the early part of 1929. The experiences of the latter company are of great significance. ${ }^{57}$ It administers between 800 and 900 wageearner cases a year. The monthly wages of the debtors in these cases: range from $\$ 90$ to $\$ 300$. The average wage is $\$ 125$ per month. The clientele includes men from all walks of life and all classes of occupation-junior executives of corporations, clerks, street car and railroad. employees, electricians, mechanics, engineers, truck drivers, artisans, etc. The average indebtedness is approximately $\$ 930$; the range is from: a few hundred dollars to over $\$ 5000$. Approximately $8.3 \%$ of the aver-

${ }^{57}$ The authors are grateful to Mr. Henry A. Coit, President of the American Amortization Co., 30 No. LaSalle St., Chicago, Ill., for most of the information on the operation and experience of that company. No publications are available respecting the company except those prepared by it for private circulation. 
age debtor's income goes for interest to loan companies; in other words, about one month's income out of the year. The average debtor owes three loan companies a total amount of $\$ 550$. Practically all such loans are secured by wage assignments and chattel mortgages on household goods.

Cases are obtained for the most part directly from the wage earners or through other wage earners who have been clients and who recommend it to their friends. Occasionally employers suggest it, infrequently creditors. One of the officers of the company analyzes the wage earner's financial condition and decides what maximum monthly, bi-weekly, or weekly payments can be made to the creditors. The debtor contracts with the company to pay such installments to it and authorizes it to disburse the payments to the creditors. The arrangement is purely voluntary on the part of the debtor. Creditors are not parties to it and hence as respects them it has no legal sanction. They can still proceed to garnish or to file assignments of wages. They can still continue their persistent demands on the debtor. Without legal sanction the debtor cannot be relieved of all the pressure. But the fact is that between him and the creditors is inserted a third party who knows the system of the collection agency, who can talk its language and call its bluff and who is not susceptible of the same degree and kind of pressure as is the wage earner. As a result, the overreaching on the part of rapacious creditors is minimized and their threats can be treated on the merits. Consequently, for the most part the debtor is enabled to proceed in a methodical and business-like way to fund his obligations through the agency of this intermediary.

The average time taken for amortization is 22 months. In but very few of the cases has the debtor made each payment under the amortization plan punctually. Most of the cases require some revision and adjustment before completion. These defaults are almost always due to some justifiable and understandable cause. It may be that a member of the family was injured or ill and the money was needed for those expenses. Wages may have been reduced or employment curtailed. The fact remains that during the three years of its existence the company has been able completely to amortize the indebtedness of the wage earners in the vast majority of the cases which it has taken over. With minor exceptions, failure to amortize was due to the insistence of creditors that they be paid according to the letter of the contract.

The company is not an eleemosynary institution. It is in the business for profit. Its charges average about $4 \mathrm{r} / 2 \%$ of the total indebtedness. This is paid not by the creditors but by the debtor. For that charge he is able to avoid bankruptcy, keep his job, and obtain relief from much of his anxiety and fear. 
How representative the conditions in Illinois are is not known. Certainly the cases studied in Boston do not approach those cases in the severity of the problem of the loan company. Yet from what has been said previously it is clear that other urban centers present as extreme conditions as Illinois. ${ }^{58}$ The severity of the practices of loan companies, however, is not the determining factor in providing for amortization. That is bottomed on the pressure of the creditors and the inherent honesty and respectability of the debtors.

It would seem desirable to provide in the Bankruptcy Act for such procedure. The wage earner should be able to advise the court or other official in charge that he desires to amortize. The creditors and the bankrupt should be permitted a hearing to determine what funding would be feasible and practicable. In the light of the facts of the particular case the bankruptcy official in charge should be able to declare a moratorium, restrain creditors from their attempts at collection and undertake a payment of the debts over a term. Or an amortization plan should be allowed to be submitted on behalf of the debtor by such a company as the American Amortization Company, duly qualified and bonded by the court to act in such capacity, and a hearing be given on the plan submitted. On the basis of the plan as approved, amortization should be allowed, reserving to the court residuary jurisdiction to control the administration for the interests of all parties and to supervise the fees charged.

If the experience of the American Amortization Company proves to be representative, defaults would be made by the debtors under these amortization plans. In the event of such default the creditors, debtor and amortization agency should be entitled to a hearing. If it should appear that the default is not justified under all the circumstances of the case, the court or official in charge should be able to adjudge the debtor a bankrupt and thereupon proceed to administer the estate in the normal way. If, as previously suggested, there is power to refuse, suspend or grant, conditionally or unconditionally, a discharge, the case can be disposed of in light of its peculiarities. Such threat of refusal, suspension or conditional grant of the discharge should serve effectively as a deterrent to prevent unjustifiable defaults under amortization plans. On the other hand, a default might well be justified due to the subsequent intervention of sickness, unemployment, etc. In such case the court or other official should have the power after such hearing to revise the plan and reinstate the program on a new basis. Obviously such default should not be grounds for suspending, denying or conditionally granting the discharge.

${ }^{s 8}$ See note 52 , supra. 
A few other aspects of such a proposal should be noted. In the first place, amortization should not be mandatory on the part of the debtor. There is no apparent reason why the debtor should be discriminated against just because he is a wage earner. Under the provisions suggested above concerning assignments, extensions and compositions, the business man has the option to go through bankruptcy or to cooperate with his creditors in making satisfactory and equitable settlements or adjustments. His honesty and desire for respectability may lead him to choose the latter course. To permit him to have such an option and to deprive the wage earner of it would be to enact a species of unwarranted class legislation. Further, the wage earner may be in such straightened circumstances as to make any attempt impossible. As noted above, of the 221 Boston salaried bankrupts, 5\% received no salary during the year preceding bankruptcy, and $21 \%$ less than $\$ 1000$. Hence refusal to amortize should not under any circumstances be a ground for refusing, suspending or conditionally granting a discharge.

In the second place, the debtor should be allowed to amortize even though he has not obtained the consent of a certain percentage of his creditors. The retailer, manufacturer, etc., is in a better position to bargain and negotiate with his creditors than the wage earner. The latter is dominated by them and incapable of such negotiations. While an amortization company would be in a better position in that regard, the fact remains that there are so few of them at present as to make their presence negligible in the totality of the national bankruptcy system. The chances are that creditors would desire to get something rather than nothing and agree to such a plan. The court or other official then should have the power to inaugurate it. The point has another significance. If such consent was not made a condition to amortization, funding programs outside of court would be encouraged. Any agency which had obtained the debtor's consent to amortize could deal effectively (but fairly) with rapacious creditors by a counter-threat to file the plan in court. Thus additional encouragement would be given to voluntary settlements.

In the third place, the debtor should not be forced by the court or other official to amortize all his debts or none. It may be that the burden would be so great as to make an attempt impracticable. Here again there is no apparent justification for class legislation. Under the provisions suggested above for businesses, a settlement might be approved netting less than 100 cents on the dollar. Such adjustments would be made in light of available assets and prospective earnings of the business. Like adjustments should be made possible in wage earner cases 
on the basis of future earning capacity. To restrict the alternatives to amortization of all debts or bankruptcy would make it impossible for the honest debtor to meet his creditors half way. That is made clear by the 221 salaried bankrupts studied in Boston. As noted previously, their average salary for the year preceding bankruptcy was only $\$ 1526 ; 5 \%$ received no salary; $21 \%$ less than $\$ 1000 ; 46 \%$ less than $\$ 1500$. In this connection provision for amortization should be sufficiently flexible to permit cancellation of all or part of the interest during the amortization period. Where the interest amounts to sizable sums as it apparently does in Chicago and Louisville, ${ }^{59}$ the burden of carrying those charges through amortization might well be so great as to defeat the funding plan.

Finally, there is the need of defining the term "wage earner." Under the present act it is defined as one whose yearly salary does not exceed $\$ 1500 .^{60}$ On the basis of the experience of the American Amortization Company that description embraces the average case. But it excludes many others whose salaries exceed that amount but whose situation in many respects is on all fours with that of their lower paid brethren. For example, in the 221 Boston cases referred to, it would exclude $51 \%$ of the cases. Among the 221 Boston cases there is very little, if any, distinction between the cases where the income was below $\$ 1500$ and the cases where it exceeded that amount. As respects them, the distinction drawn in the bankruptcy act is wholly arbitrary. A less arbitrary distinction would be between the salaried class and entrepreneurs. Some upper limit might be set. But conceivably the amortization procedure might be as effective and desirable in the case of the $\$ 10,000$ a year executive as in the case of the $\$ 1000$ a year clerk.

\section{Summary Administration}

Even if the foregoing suggestions concerning amortizations, extensions and assignments should be incorporated into the Bankruptcy Act, still a great number of small debtors will probably continue to appear before the bankruptcy courts. For such small asset cases some form of summary administration in which speed and economy are the dominant features is necessary.

The cases with small assets or no assets have been discussed early in this article. It will be recalled that for the nation as a whole, $82 \%$ of all cases closed during the fiscal year ended June 30, 1930, had either no assets or assets below $\$ 500$; and that $65 \%$ had no assets whatsoever, over and above exemptions. In these cases the administration

${ }^{39}$ Supra 50; note 52, supra.

${ }^{\infty 0} \$ 1$ (27). 
expenses averaged $85 \%$ for cases with assets from $\$ 1-\$ 100$; and $63 \%$ for cases with assets from $\$ 251-\$ 500$. The data for the New Jersey cases was quite comparable. It has also been noted above how inactive and lethargic the creditors became in such cases. Furthermore, among the New Jersey bankrupts studied, it required, on the average, twelve months to wind up those cases in which assets totaled less than $\$ 500$. By way of comparison the average time required to liquidate all those cases above $\$ 5000$ was only about 17 months. Possibly time is not of the essence in liquidating the large estates, but it certainly seems that the system of bankruptcy administration should be made sufficiently flexible to permit more rapid handling of the small bankruptcy.

In this connection, a new section should be added to the Bankruptcy Act modeled after that section of the English act $^{61}$ which provides that summary administration may be had in "small bankruptcies," defined as those in which the assets are not "likely to exceed in value $£ 300$." 62 The new section suggested should empower the referee or court to extend a summary procedure to cases where realized assets will probably not exceed, say, $\$ 500$. Following such determination, unless there is objection from a certain number of creditors, there should be instituted a scheme of summary administration whereby most of the many notices to creditors and their subsequent waiting periods would be dispensed with and the six months period for filing proofs of claim cut down to one or two months.

In other words there seems to be no forceful reason for applying to such cases the elaborate and detailed procedure designed for and necessary in cases of the larger estates. But in such administrative details and in them only should distinction be made between the small and large cases. The same rigorous and systematic examination and the same methods in dispensing discharges should be employed in all cases. Thoroughness should not be sacrificed for expedition; vigilance for speed.

\section{ConCLUSIONS}

In light of the above data and observations, the following revisions of the Bankruptcy Act are suggested:

1. In all cases where there are no assets (above exemptions) or

${ }^{\text {61 }} 4$ \& 5 Geo. V, § 129 (1914). And see Bankruptcy Rule 298 (1915-1928), which provides that in small bankruptcies, advertisement of proceedings is to be dispensed with, no questions of law and fact may be referred to a jury, the time and place and number of creditors' meetings may be limited, notices of meetings need be sent only to creditors whose claims exceed $£ 2$, and the estate shall be liquidated with all reasonable dispatch and where practicable, distributed in a single dividend.

${ }^{62}$ See Donovan, supra note 4 , at 176 , for a description of the procedure under that act. 
assets below, say, $\$ 5000$, the trustee should be appointed by the court or referee; only in other cases should creditors have the power to elect a trustee.

2. Compulsory and thorough examination of every bankrupt, the examination to be preceded by submission on the part of the debtor of a verified statement showing not only his assets and liabilities but also the antecedents of his failure.

3. Compulsory and systematic hearing on every application for a discharge.

4. Discretion on the part of the court, or other official empowered to dispense discharges, to refuse, suspend, or grant them, conditionally or unconditionally, in the light of the facts and complexions of the cases.

5. Eliminating a general assignment for the benefit of creditors as an act of bankruptcy in specified cases where the assignment is filed and accepted; providing machinery for filing specified assignments, extensions and compositions with the court, and, on acceptance thereof by the court, extending to such arrangements immunity from attack by minorities, and supervision by the court of their administration; and endowing the assignee-trustee thereunder with the powers of a trustee in bankruptcy.

6. Providing for amortization of debts by salaried bankrupts at their option, sufficient flexibility being provided to allow for partial amortization and readjustments of funding programs and no penalty being imposed for mere failure or refusal to amortize in full or in part.

7. Segregation of no asset cases and cases with assets below, say, $\$ 500$, for summary administration.

William O. Douglas

J. Howard Marshall

Yale Law School 